Chapter 5

\title{
EVOLUTION OF AGRICULTURAL MECHANIZATION IN THAILAND
}

Rob Cramb and Viboon Thepent

\begin{abstract}
Evidence from Asia indicates that mechanization can play a vital role in poverty-reducing small-scale agricultural and rural development. The case of Thailand is especially pertinent because it illustrates both the development of accessible small-scale machinery and the provision of large-scale machinery to smallholders through contract hiring services. This chapter reviews the specific demand and supply factors that have given rise to the pattern of mechanization in Thailand over the past half century. It is argued that rapid mechanization resulted from the conjuncture of several key elements from the 1960s to the 1990s-the dominance of smallholders in the landscape, cultivating rice and field crops for both domestic and export markets; dramatic demographic changes, contributing to a growing scarcity of agricultural labor; a boom in manufacturing, drawing labor out of farming; the development of infrastructure, facilitating agricultural commercialization and labor mobility; a technological and business environment encouraging competition among small and medium firms to develop suitable and affordable machines for farmers; and a policy environment broadly supportive of smallholder agriculture, agribusiness, industrial development, and trade. The Thailand case provides important evidence for policy debates about small-scale mechanization in other Southeast Asian countries and Africa south of the Sahara.
\end{abstract}

\section{Introduction}

Over the past five decades, the agricultural sector in Thailand has experienced one of the most rapid and extensive processes of mechanization in Southeast Asia, in which the distinguishing feature has been the development of locally adapted small-scale machinery to meet the needs of agricultural smallholders. This began in the 1960s and 1970s with the importation and local manufacture of pumps and two-wheel tractors (2WTs) used in rice cultivation, particularly in the central plain of the Chao Phraya River, in the Central region (Figure 5.1). Mechanization was extended progressively to the use of small 
rice mills, sprayers, threshers, and combine harvesters, not only in the central plain but also in the lowland rice-growing and upland field-crop zones of the Khorat Plateau in the Northeast region (Figure 5.1). The number of 2WTs in use increased from around 90,000 in 1975 to 2.7 million by 2008, representing a growth rate of 11 percent and a density in 2008 of 0.14 per hectare of agricultural land, or just over 7 ha per machine (Chancellor 1983; Coxhead and Plangpraphan 1998; Thepent 2000, 2015). Correspondingly, the number of buffalo, the main source of draft power in rice farming before the advent of the 2WT, declined from a peak of 6.4 million in 1982 to just over 1.0 million in 2014 (FAO 2017).

The current usage of machinery and equipment on farms in Thailand is recorded in Table 5.1, showing that 41 percent of holdings use $2 \mathrm{WTs}$, 41 percent use four-wheel tractors (4WTs), 20 percent use planters, 30 percent use small water pumps, 44 percent use sprayers, 37 percent use weeders, and 29 percent use combine harvesters. Apart from $4 \mathrm{WTs}$, threshers, and combine harvesters, which are predominantly sourced from private service providers, most of this machinery and equipment is owned by the landholder, notably in 75 percent of cases for 2WTs and 76 percent of cases for engine-powered pumps. Moreover, most is manufactured in Thailand by a large number of small to medium-size private engineering firms, some of which now export machines to neighboring countries. In 2009 there were reported to be 275 firms manufacturing 2WTs, 386 firms manufacturing combine harvesters, and 1,192 firms providing repairs and maintenance for agricultural machines (Thepent 2015).

The explanation for this rapid mechanization of Thai agriculture lies in the conjuncture of several key elements:

- The nature of farming in Thailand, dominated by smallholders, with farms averaging around 3 ha, cultivating rice and field crops for both domestic and export markets;

- Dramatic demographic changes, especially a rapid drop in birth rates, contributing to a growing scarcity of agricultural labor;

- A boom in manufacturing and construction in the 1980s and 1990s, drawing labor out of farming, particularly in younger age groups, a process that has continued at a slower rate in subsequent decades;

- The development of transport and communication infrastructure, facilitating agricultural commercialization and labor mobility; 
FIGURE 5.1 Regions of Thailand

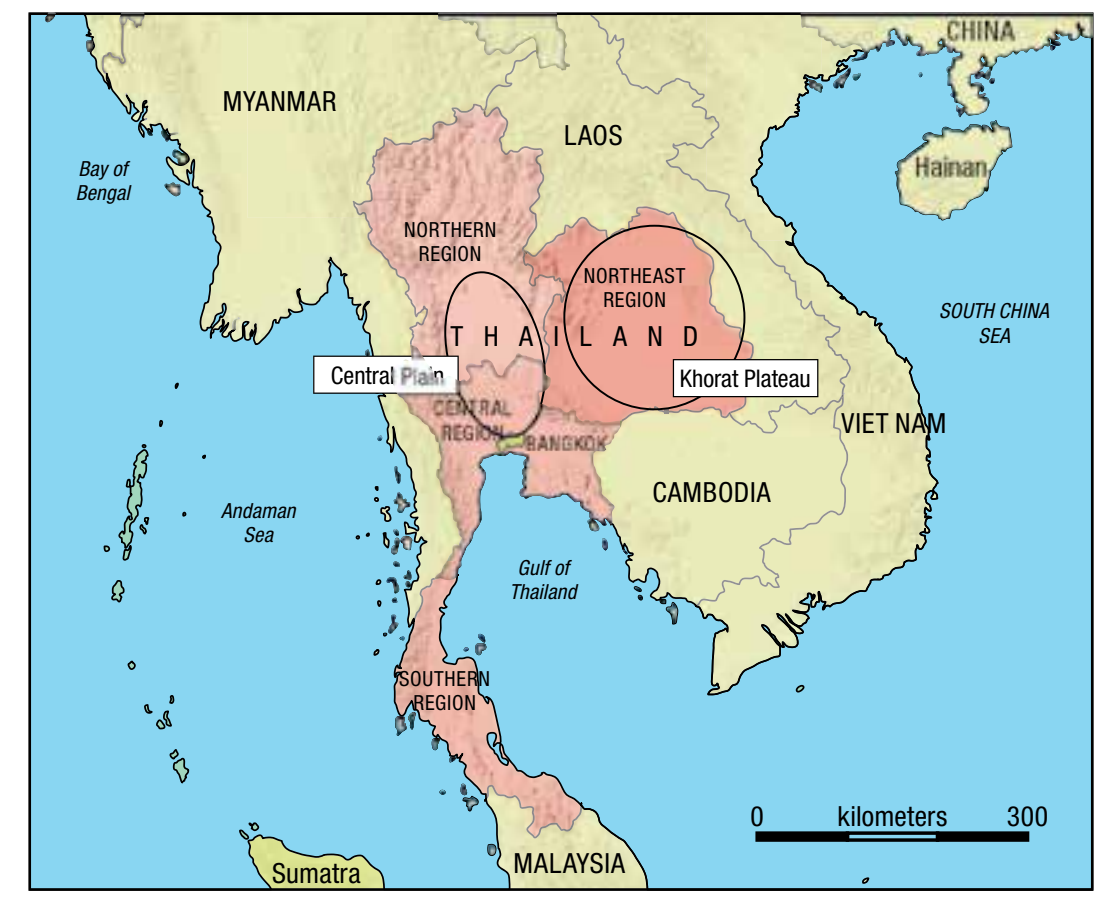

Source: Australian National University (2019).

- A technological and business environment encouraging competition among small and medium-size firms to develop suitable and affordable machines for farmers;

- A policy environment generally supportive of smallholder agriculture, agribusiness, industrial development, and trade.

This chapter elaborates on this historical conjuncture, examining both the demand and supply sides of the story. First, the chapter describes the longterm economic and demographic changes that have given rise to labor scarcity in agriculture, and the trends in agricultural development that have led farmers to make greater use of machinery, focusing on the crops for which mechanization has been in greatest demand and had the greatest impact, namely, rice and commercial field crops. Second, the story of mechanization itself is outlined and the factors enabling the rapid growth in the supply of suitable farm machinery and machinery services are analyzed. The chapter concludes with 
TABLE 5.1 Number of holdings using farm machinery and equipment by source, Thailand, 2013

\begin{tabular}{|c|c|c|c|c|c|c|c|}
\hline \multirow[b]{2}{*}{ Type of machinery } & \multirow[b]{2}{*}{$\begin{array}{c}\text { No. of } \\
\text { holdings }\end{array}$} & \multirow[b]{2}{*}{$\begin{array}{c}\% \text { of } \\
\text { holdings }\end{array}$} & \multicolumn{5}{|c|}{ Source of machinery or equipment } \\
\hline & & & $\begin{array}{l}\text { Owned by } \\
\text { landholder }\end{array}$ & $\begin{array}{l}\text { Co-op or } \\
\text { farmer } \\
\text { group }\end{array}$ & $\begin{array}{l}\text { Service } \\
\text { provider }\end{array}$ & $\begin{array}{l}\text { Govern- } \\
\text { ment } \\
\text { agency }\end{array}$ & Other \\
\hline \multicolumn{8}{|l|}{ Tractor } \\
\hline 4-wheel tractor & $2,427,001$ & 41.1 & 336,735 & 4,869 & $2,056,174$ & 2,966 & 6,361 \\
\hline 2-wheel tractor & $2,438,848$ & 41.3 & $1,827,555$ & 5,631 & 643,863 & 1,884 & 14,359 \\
\hline \multicolumn{8}{|l|}{ Water pump } \\
\hline Engine & $1,376,690$ & 23.3 & $1,049,403$ & 11,340 & 316,503 & 9,892 & 13,871 \\
\hline Electrical motor & 330,474 & 5.6 & 283,443 & 2,767 & 48,364 & 11,309 & 1,789 \\
\hline Natural energy & 32,758 & 0.6 & 17,989 & 1,125 & 14,589 & 2,442 & 1,690 \\
\hline \multicolumn{8}{|l|}{ Sprayer } \\
\hline Manually operated & $1,273,177$ & 21.5 & 856,546 & 2,264 & 418,894 & 1,049 & 8,082 \\
\hline Machine-powered & $1,323,153$ & 22.4 & 845,773 & 2,476 & 489,336 & 1,266 & 6,104 \\
\hline \multicolumn{8}{|l|}{ Weeder } \\
\hline Manually operated & $1,053,087$ & 17.8 & 673,112 & 1,778 & 373,144 & 803 & 8,699 \\
\hline Machine-powered & $1,155,443$ & 19.5 & 748,969 & 1,542 & 379,050 & 1,155 & 5,880 \\
\hline \multicolumn{8}{|l|}{ Planter/seeder } \\
\hline Manually operated & 720,999 & 12.2 & 268,000 & 2,140 & 497,155 & 827 & 17,764 \\
\hline Machine-powered & 167,413 & 2.8 & 62,600 & 438 & 110,424 & 163 & 682 \\
\hline Att. to 2-wheel tractor & 131,381 & 2.2 & 73,237 & 357 & 60,179 & 161 & 858 \\
\hline Att. to 4-wheel tractor & 192,569 & 3.3 & 37,120 & 427 & 156,223 & 258 & 639 \\
\hline \multicolumn{8}{|l|}{ Harvester } \\
\hline Reaper (sugar) & 82,044 & 1.4 & 3,047 & 686 & 78,953 & 238 & 258 \\
\hline Combine harvester & $1,639,016$ & 27.7 & 33,095 & 3,123 & $1,588,239$ & 2,456 & 2,646 \\
\hline \multicolumn{8}{|l|}{ Thresher } \\
\hline Rice/cereal thresher & 542,887 & 9.2 & 14,512 & 2,652 & 526,713 & 1,449 & 2,544 \\
\hline Corn sheller & 173,568 & 2.9 & 4,027 & 1,328 & 168,737 & 256 & 1,077 \\
\hline Rice/cereal winnower & 207,718 & 3.5 & 4,777 & 3,302 & 201,873 & 714 & 1,969 \\
\hline Rice mill & $1,808,871$ & 30.6 & 40,515 & 59,847 & $1,752,898$ & 9,130 & 25,564 \\
\hline Milking machine & 11,707 & 0.2 & 7,622 & 102 & 4,091 & 28 & 96 \\
\hline \multicolumn{8}{|l|}{ Transportation } \\
\hline 4-wheel truck & $1,744,370$ & 29.5 & 799,979 & 3,177 & 931,162 & 1,772 & 15,695 \\
\hline 6-wheel (and over) truck & $1,037,262$ & 17.5 & 84,563 & 2,483 & 951,690 & 1,379 & 3,112 \\
\hline Boat & 29,256 & 0.5 & 26,362 & 44 & 2,733 & 42 & 161 \\
\hline Farm truck & 943,220 & 16.0 & 499,030 & 3,001 & 459,441 & 1,427 & 9,521 \\
\hline
\end{tabular}

Source: Thailand, NSO (2013). 
a summary of key lessons for the debate on agricultural mechanization and its contribution to rural development.

\section{Factors Affecting the Demand for Mechanization}

\section{Economywide Structural and Demographic Change}

Thailand has experienced remarkable economic growth in the past five decades, raising its economic status from that of a low-income to an upper-middleincome country (Warr 2007; World Bank 2016). Economic growth accelerated to around 8 percent from the mid-1980s to the mid-1990s due mainly to a surge of Japanese investment in labor-intensive manufacturing industries such as garments, textiles, and footwear in and around Bangkok. The automotive and electronics industries also began to expand, and urban property development boomed. Hence a significant gap opened up between agricultural and nonagricultural wage rates, especially nonagricultural wages in Bangkok (Figure 5.2). The Asian financial crisis caused a major reversal in 1997/1998, but by 1999 rapid economic growth had resumed, continuing for another decade until the global financial crisis of 2007/2008. Since then growth has continued, albeit falteringly due to a combination of domestic and global instability, with growth in 2015 recorded at 2.8 percent (World Bank 2016).

This long-term growth trajectory has been associated with major structural change in the Thai economy (Coxhead and Plangpraphan 1998; Poapongsakorn 2006; Warr 2007, 2014; Leturque and Wiggins 2011; Cramb and Newby 2015; Klyuev 2015; Ouyyanont 2016; World Bank 2016). Although the agricultural sector also experienced steady growth, as noted above, its share of GDP declined. Agriculture's value-added grew at 3-4 percent in real terms from 1960 to 2014, but it declined as a proportion of gross domestic product, from 37 percent in 1960 to 8 percent in 1993, and has hovered around 10 percent since then. At the same time, agriculture's share of total employment fell from 71 percent in 1980 to around 42 percent in 2004, also fluctuating around the same proportion in the succeeding decade. This proportion is considered high for a country of Thailand's economic status (Klyuev 2015), possibly reflecting an overstatement of the degree to which rural households still depend primarily on agriculture; the number of full-time farmers declined from 16.3 million in 1992 to 9.6 million in 2010, which was about 27 percent of total employment (World Bank 2016, 27).

The long-term decline in agricultural employment in Thailand has been partly offset by an influx of migrant workers from surrounding countries 
FIGURE 5.2 Monthly wage rates in Thailand by sector, 1980-1995

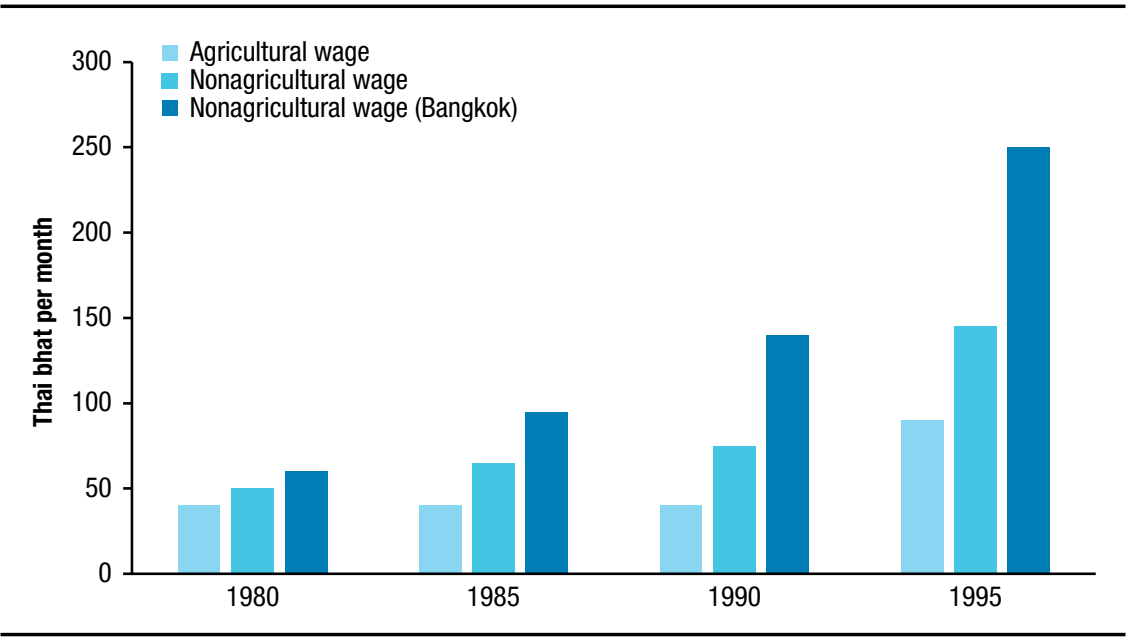

Source: Coxhead and Plangpraphan (1998).

(Myanmar, Laos, and Cambodia) in recent decades, who are paid lower wages than Thai workers. Thailand currently has about 3.7 million migrant workers, accounting for almost 10 percent of total employment (World Bank 2016, 28). However, it is estimated that migrant workers contribute only about 5 percent of the agricultural workforce, mainly working on specialized commercial farms, and have not greatly affected the trend toward mechanization on the majority of smallholder crop farms.

Alongside this economic transformation has been a major demographic transition (De Koninck and Rousseau 2012; Rigg 2012; Cramb and Newby 2015). In the 1960s Thailand was experiencing rapid population growth (around 3 percent) due to a high birth rate and a much reduced death rate. Given that more than 80 percent of the population was rural and a similar proportion of the workforce was engaged in agriculture, this was creating concern about, on the one hand, population pressure in the central lowlands, causing land fragmentation and increased landlessness (Ramsay 1985), and on the other, the spread of lowland Thai rice farmers into the forested uplands of the Northern region (Chapman 1978). It also gave rise to concern in some quarters about the labor-displacing effects of mechanization.

However, a complex of factors (economic growth, urbanization, and an effective family planning policy) led to a sharp drop in the birth rate from the mid- to late 1960 s, such that the population growth rate fell to only 
0.3 percent in 2013 (World Bank 2016). This dramatic slowing in the rate of population growth, combined with the movement of labor from agriculture to urban-based industry and services, led to reduced growth and then, beginning around 2000, an absolute decline in the rural population such that, by 2015, the urban population just exceeded the rural population in a total population of 68 million.

\section{Pattern of Agricultural Development}

\section{LANDHOLDINGS AND FARMING SYSTEMS}

Thailand has a land area of 51 million ha, of which 43 percent is agricultural land, allocated mainly to lowland rice ( 51 percent); field crops such as maize, cassava, and sugarcane (22 percent); and tree crops, notably rubber and oil palm (22 percent) (Table 5.2). The high percentage of agricultural land results in a ratio of 0.3 ha per person, more than in most Southeast Asian countries (Cramb 2015). Thus, although Thailand is not a "land-abundant" economy, it has a relatively favorable land endowment.

There were almost 6 million agricultural holdings recorded in the 2013 agricultural census (Thailand, NSO 2013). The number of holdings had increased by 2.0 percent since the 2003 census, and the total area had increased by 1.9 percent, so the average holding size remained stable at 3.2 ha-again, relatively large by Asian standards. Almost all holdings (98.9 percent) were held by individual households, accounting for 98.5 percent of the total area. Most holdings (91.0 percent) comprised 1-3 parcels, representing 75.1 percent of the total area.

The incidence of ownership was high in 2013, with 78.7 percent of holdings owned, 11.3 percent non-owned (borrowed or rented), and 10.0 percent comprising both owned and non-owned parcels. About 63 percent of land parcels were registered, providing secure tenure, though unregistered rights are also considered relatively secure, except in forest reserves and areas at risk of land expropriation by developers (USAID 2011).

The size distribution of holdings was somewhat unequal. Whereas the middle 50 percent of holdings, in the range 1.45-6.24 ha, contained 50 percent of the area, the upper 12 percent of holdings contained 41 percent of the area, mostly in the 6.25-80 ha range, and the lower 37 percent of holdings $(<1.45 \mathrm{ha})$ contained 9 percent of the area. Nevertheless, it is true to say that the overall agrarian structure is "unimodal" (Tomich, Kilby, and Johnston 1995), dominated by independent farm households operating their own, relatively compact smallholdings. 
TABLE 5.2 Holding size and land use by region, Thailand, 2013

\begin{tabular}{lrrrrr}
\hline & \multicolumn{5}{c}{ \% of total area in region } \\
\cline { 2 - 6 } Variable & Central & North & Northeast & South & Thailand \\
\hline Rice & 42.4 & 50.1 & 67.5 & 5.7 & 51.3 \\
Rubber & 8.5 & 3.2 & 8.2 & 66.7 & 14.5 \\
Permanent crops & 13.1 & 7.7 & 0.9 & 24.2 & 7.5 \\
Field crops & 27.2 & 34.8 & 20.5 & 0.3 & 22.4 \\
Horticultural crops & 2.0 & 1.1 & 0.3 & 0.6 & 0.8 \\
Forest (planted) & 1.5 & 1.5 & 0.6 & 0.2 & 0.9 \\
Freshwater culture & 2.9 & 0.2 & 0.2 & 0.4 & 0.7 \\
Other & 2.4 & 1.4 & 1.8 & 2.0 & 1.8 \\
Total & 100.0 & 100.0 & 100.0 & 100.0 & 100.0 \\
\hline Mean area/holding (ha) & 3.7 & 3.4 & 3.2 & 2.3 & 3.2 \\
\hline
\end{tabular}

Source: Thailand, NSO (2013).

The type of land operated by these smallholders varies considerably across the country's four main regions (Figure 5.1). The Central region includes the historical rice bowl, with fertile soil, 60 percent irrigable land, high population density, and good access to markets. It was also the first region to commercialize and diversify into crops such as sugarcane, rubber, and horticultural crops. The number of agricultural holdings in this region declined between 2003 and 2013; so too did the average holding size-from 3.9 to 3.7 ha-which nevertheless remains the highest in the country (Table 5.2). Despite its historical significance, the region accounts for only 14 percent of all holdings in the country and 17 percent of total area.

The Northern region is largely mountainous, with low population density. It was traditionally associated with long-fallow swidden agriculture but has seen an increase in the area of lowland rice cultivation in the upper part of the central plain and in inland valleys ( 34 percent of the region's arable land is irrigable) and an expansion of field crops (especially maize) and horticultural crops on sloping land. It has also seen a decline in the number of holdings but an increase in the average holding size, from 3.0 ha in 2003 to 3.4 ha in 2013, not far below the Central region average (Table 5.2). Overall, the region accounts for 22 percent of holdings and 24 percent of farm area.

The Northeast region has poor, often sandy soils, less reliable rainfall, and low productivity but accommodates almost half of Thai farm households. Rainfed lowland rice is the dominant crop (only 13 percent of the 
region's arable land is irrigable), but the region has seen significant growth of export-quality rice and expansion of cassava, sugarcane, and rubber in recent decades, particularly in the northern part (Ekasingh et al. 2007; Grandstaff et al. 2008; Table 5.2). The number of holdings has been increasing, but the average holding size has remained constant at 3.2 ha (Table 5.2). The Northeast accounts for 46 percent of holdings and 47 percent of area.

The Southern region has little flat land but has ideal agroecological conditions for tropical tree crops, notably rubber and oil palm, which take up 91 percent of agricultural land (Table 5.2). The number of holdings has been increasing and the average area decreasing, from 2.8 to $2.3 \mathrm{ha}$. This region accounts for 17 percent of holdings but only 13 percent of total farm area.

\section{PHASES OF AGRICULTURAL GROWTH}

Agricultural growth was relatively rapid in the 1960s and 1970s, averaging 4-5 percent, but slowed with the boom in manufacturing beginning in 1985 and has fluctuated around 2-3 percent in the past decade. There have been two distinct phases in Thailand's postwar agricultural growth-extensive growth up to 1990, followed by intensive growth since then (Poapongsakorn 2006; Leturque and Wiggins 2011). As can be seen in Figure 5.3, in the 1970s and 1980s, both the area of agricultural land and the size of the agricultural workforce increased as a rapidly growing rural population pushed out the agricultural frontier, particularly in the Northern and Northeast regions, contributing to extensive deforestation. However, the expansion of farmland could not prevent the ratio of agricultural land per worker from falling, from about 1.8 ha in the early 1970 s to just over 1.0 ha in the late 1980 s. The turning point was around 1990, which marked the peak of agricultural land expansion and the beginning of an absolute decline in the agricultural workforce. Hence agricultural land per worker began to rise, slowed by the Asian financial crisis in $1997 / 1998$, but returning to nearly 1.8 ha in 2014 .

Whereas the pre-1990 phase of agricultural growth was dependent on increases in aggregate inputs of land and labor, the post-1990 phase has been driven by increased productivity resulting from investment in capital (particularly mechanization) and technological improvement (particularly improved crop varieties), roughly in the ratio 60:40 (Leturque and Wiggins 2011). Hence value-added per agricultural worker, which had been unchanging in the 1970 s and 1980 s, rose sharply, from $\$ 530^{1}$ in 1990 to $\$ 1,260$ in

1 Dollar amounts are in US dollars throughout the chapter. 
FIGURE 5.3 Agricultural land, agricultural employment, and land-to-worker ratio in Thailand, 1971-2014

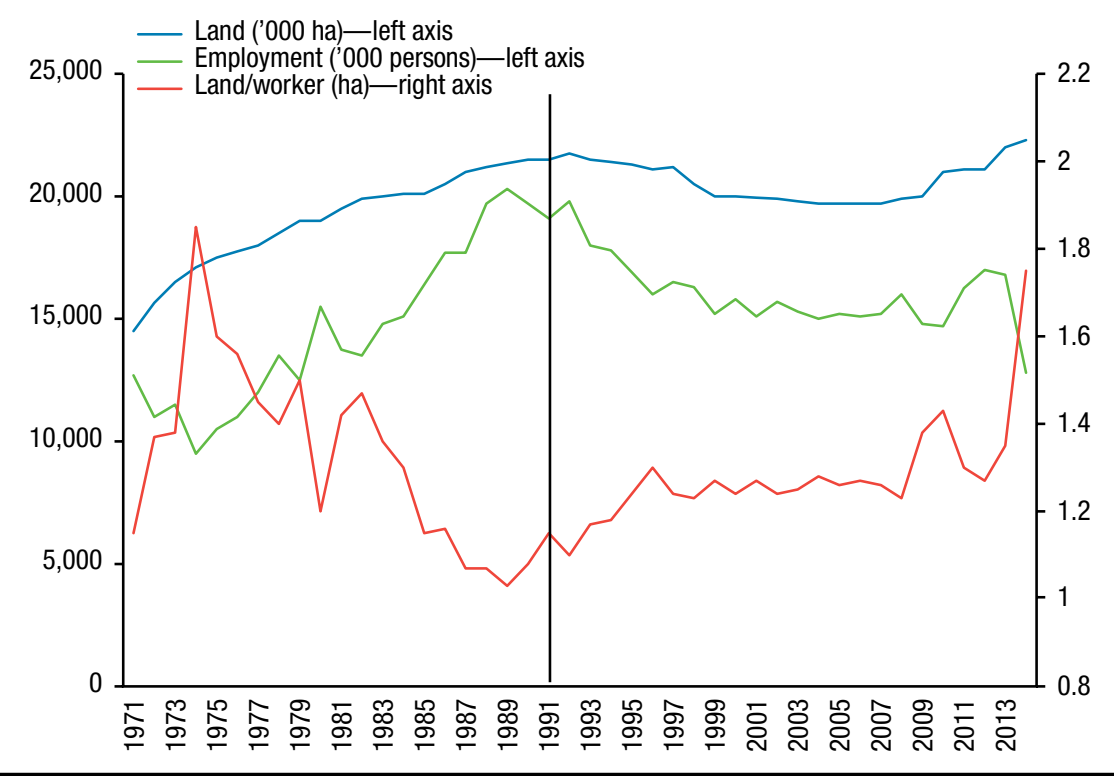

Source: World Bank (2017).

2013, though still well below valued-added per worker in the industrial sector. Farmers sourced the capital for this investment from their savings and by borrowing from the highly successful Bank for Agriculture and Agricultural Cooperatives and other formal and informal sources (including dealer credit for larger items of machinery). This phase of agricultural growth has not only been characterized by intensification of land use (notably, a shift to two or more crops per year in the irrigated central plain) but also greater diversification into high-value nonrice crops (fruit, vegetables, and flowers) particularly in the Central and Northern regions. It has also seen the emergence of more specialized, professional farmers, estimated to account for 20 percent of all farmers in 2004, many of them in contract-farming arrangements with agribusiness firms (Poapongsakorn 2006, 40-43; Leturque and Wiggins 2011, 22-23).

Throughout these two periods, Thai agriculture has been strongly export oriented, with rice, sugar, cassava, rubber, palm oil, poultry, and aquaculture all contributing. Before the manufacturing boom of the 1980s, most exports were of agricultural origin, and agriculture still contributes 25 percent of total exports by value (Poapongsakorn 2006; Singhapreecha 2014). 


\section{Crop-Specific Factors Affecting Demand for Mechanization}

The mechanization of agriculture has been largely a story of lowland rice and the major commercial field crops-sugarcane, cassava, and maize. Mechanization of the major tree crops-rubber and oil palm—has proved more elusive. The impetus for mechanization came not only from the declining availability and increasing cost of farm labor due to the exogenous economic and demographic trends described above, but also from trends within the crop subsectors that increased the demand for labor, adding to its cost. In the case of rice, the impetus for mechanization came from the shift to more intensive production, especially double cropping, made possible by irrigation and Green Revolution technologies, in the context of a growing export market (Fujimoto, Adulavidhaya, and Matsuda 1990). In the case of the major field crops, the impetus came from export booms that made areal expansion (and eventually increased yields) profitable (De Koninck and Rousseau 2012). This combination of relatively elastic demand for farm output and an increasing cost of labor induced farmers to demand suitable labor-saving capital inputs in order to reduce costs and maintain profitability (Binswanger 1986; Pingali 2007).

\section{RICE}

Rice is still the most important crop in Thailand, accounting for just over half of agricultural land (Table 5.2). Rice is mainly grown in the central plain, of which a high proportion is irrigated, enabling double cropping, and on the Khorat Plateau, where it is mainly rainfed, permitting only a single wet-season crop. From the 1960 s to the 1980 s, growth in rice production was largely due to expansion of the area cultivated (from about 6 million ha to 10 million ha), especially in the Northern and Northeastern regions, with little improvement in yields, which were low by Asian standards, averaging 1.8 tons/ha. ${ }^{2}$ In the 1990s, area expansion ceased but average yields increased at about 2.5 percent, continuing through to the present-they now average 3.0 tons/ha. This was due to the ongoing and widespread use of high-yielding varieties (HYVs), increased fertilizer application, and improvements in irrigation. Total rice production has increased at a rate of more than 10 percent since 1990 due to a combination of increased yield and (since 2000) greater cropping intensity. Thailand has long been one of the two or three major exporters of rice, peaking at 10.8 million tons of milled rice, valued at \$5.4 billion, in 2014 . Rice exports were heavily taxed up to the late 1990 s, but in recent years the

\footnotetext{
2 "Tons" refers to metric tons throughout the chapter.
} 
state has introduced price-support schemes (with disastrous political and economic consequences).

Up to the 1950s, most rice farming in Thailand used a traditional set of labor-intensive and time-consuming technologies-land preparation by buffalo-drawn shovel-plow and harrow; irrigation (where feasible) using scoops, water wheels, or a wooden water-lift trough; pulling and transplanting seedlings by hand; weeding with a knife or sickle; harvesting by sickle (or a finger knife in the Southern region); threshing sheaves with hand-held sticks or by animal trampling; and dehusking the grain (as required) using a wooden mortar and pestle (Jongsuwat 1980; Chinsuwan and Cochran 1986). The peak labor demands were for transplanting and harvesting, with land preparation a slow and laborious process. Beginning in the 1960 s, all of these operations, except transplanting, were progressively mechanized, beginning in the central plain.

The earliest machines used were 2WTs for land preparation and low-lift axial flow pumps for irrigation, powered by single-cylinder engines. Farmers acquired these machines themselves, given their low cost and their multiple functions, ${ }^{3}$ but there was also some localized renting, particularly in the Northeast. As Pingali (2007) pointed out, such machines are generally the first to be utilized because they contribute to power-intensive rather than controlintensive tasks. Though land preparation was not the major labor peak, the advent of double cropping in the irrigated areas created a major bottleneck in the turnaround from the wet-season to the dry-season crop. A survey in the early 1970s found that "the increase in tractor use and ownership were wholly due to double cropping since the use of buffalo was too slow given the existing farm size and household labor supply" (Jongsuwat 1980, 23). Threshing and transportation were also highly mechanized for the same reason. Jongsuwat concluded that "the use of tractors and other farm machines is a matter of necessity in double cropping" $(1980,23)$. Thus mechanization (through both tractors and pumps) allowed the advantages of the HYVs to be realized.

Rather than mechanize transplanting (a control-intensive task), farmers almost universally reverted to direct seeding to save labor, using hand broadcasting of presoaked seed in irrigated areas or dry seed in rainfed areas (Kupkanchanakul 2000; Rerkasem 2015). This was in preference to direct seeding with devices such as seed drills or drum seeders, or using

3 The tractors could be used for transportation as well as powering pumps, threshers, and other equipment. The pumps could be used to power boats. 
rice transplanters, which were expensive and required greater precision and control. However, in recent years some farmers in the Central region have started to hire contractors who use imported rice transplanters (Thepent and Chamsing 2009), and there has been limited use of a seed drill in parts of the Northeast region. Hand weeding was progressively augmented or replaced by herbicides applied with hand-operated or powered backpack sprayers.

Imported Chinese reapers were tried in the early 1980s but were generally unsuccessful. However, mobile threshers were successfully introduced in the 1970s and 1980s, mostly on a contract service basis, threshing being another power-intensive task. Threshers were superseded in the central plain beginning in the 1990s by combine harvesters, also provided by contractors, and these contract harvesting services have since spread to the Northeast region (Poungchompu and Chantanop 2016).

The dehusking of rice, whether for home consumption or sale, is now universally undertaken at local rice mills rather than in the home. With the use of combine harvesters, the grain is harvested with high moisture content and is no longer left in the field to dry. Hence now almost 90 percent of collectors and millers in the major rice production areas own mechanical dryers. Attempts to promote the use of small dryers among farmer groups were generally unsuccessful.

\section{SUGARCANE}

The area of sugarcane expanded from 63,000 ha in 1961 to 1.35 million ha in 2014, occupying 6.1 percent of agricultural land, mainly in the Central region, the southern part of the Northern region, and the Northeast region. Sugarcane was first planted in the 1950s on higher land in the central plain, and subsequently spread to the Northern and Northeast regions. Most of the growth in total production has been due to this more-than-twentyfold expansion in area rather than increased yields, which have about doubled since 1980. Sugar is produced for both domestic and export markets, and the industry has negotiated significant protection in the form of a "home price scheme" that subsidizes exports (Leturque and Wiggins 2011). In addition, the government's promotion of fuel ethanol, largely derived from molasses, is adding to the demand for sugarcane (USDA 2016). Cane production reached a new record of 105.7 million tons in 2014. Thailand is the world's second-largest sugar exporter, with exports valued at $\$ 2.6$ billion in 2015, accounting for 12 percent of world sugar trade (Weerathaworn 2015).

The expansion of sugarcane in the upland areas of the central plain in the 1950s and 1960s was limited by the lack of animal or machine power 
and consequent dependence on manual labor for land clearing and cultivation. However, by the 1970 s, imported and locally assembled 4WTs drawing disc plows and harrows were used for the heavy work of land preparation, facilitating the area expansion in the 1970s and 1980s. Srijantr reported for a sugar-growing subdistrict in the western part of the central plain that "an agricultural revolution occurred in Thung Luk Nok in 1975. In sugarcane production, farmers started to use high-yield varieties, farm machines such as four-wheel tractors for land preparation, and big trucks for transportation to factories" $(2003,129)$. Srijantr observed that "only the rich farmers or those who had accumulated enough capital could invest in the new means of production such as four-wheel tractors and big trucks" $(2003,129)$. These large farmers became entrepreneurs, hiring out their tractors and trucks to small farmers, extending credit, and buying their sugarcane to meet allocated quotas from the mills.

As labor costs continued to increase, large farmers in the central plain began to use mechanical harvesters, as well as mechanizing other operations, including planting, fertilizing, and weed control. However, among smaller farmers and in the Northeast region, to which the industry expanded, manual planting and harvesting have remained dominant (Ekasingh et al. 2007). Ding, Tangwongkit, and Tangwongkit found that "manual harvesting remained popular due to its low cost, low soil compaction, and low damage to cane roots and the subsequent ratoon crop" $(2004,33)$. Vorasayan and Pathumnakul (2014) reported that with rising wages (doubling between 1998 and 2013), mechanical harvesting was becoming more feasible and the amount harvested in this way was increasing rapidly. However, widespread use was restricted by the prevalence of small farms with short fields (giving rise to field inefficiencies) and the need to have a truck alongside the harvester at all times to collect the chopped cane, whereas with manual harvesting, trucks can come to pick up the cane at any time.

\section{CASSAVA}

Cassava was a boom crop of the 1970s and 1980s, taking advantage of an advantageous EU market for animal feed (Curran and Cook 2008). Production and exports grew rapidly, almost entirely due to expansion of cultivated area in the Northeast region, where geopolitical concerns during the Indochina conflict had prompted US funding of extensive road infrastructure. The Northeast, with its sandy soils and undulating land, accounts for about 80 percent of total cassava production (Ekasingh et al. 2007; Leturque and Wiggins 2011). In the 1990s the loss of the export window to Europe led 
to a reduction in area and output, but the development of domestic processing (for example, for ethanol) and, especially, the growth of demand from China for both starch and dried cassava led to a resurgence in production beginning in around 2000 (Tijaja 2010). Although yields showed some improvement in this period (averaging 22 tons/ha in 2014 compared with around 15 tons/ ha in the 1970s and 1980s), the growth in production was again mainly due to areal expansion in the Northeast. By 2014, cassava was planted on a record area of 1.4 million ha (6.1 percent of agricultural land), producing 30 million tons of fresh roots. These were processed into dried chips and starch for use in domestic industries (about a third) and export (about two-thirds), mainly to China. Thailand has dominated global exports of cassava products since the 1980s, in 2013 exporting 5.8 million tons of dried cassava worth $\$ 1.3$ billion and 2.4 million tons of cassava starch worth $\$ 1.1$ billion.

A recent survey in the Central, Northern, and Northeast regions found that the common methods of land preparation involved primary and secondary tillage using a 4WT drawing a standard disc plow and disc tiller (Chamsing 2013). Many farmers in the Northeast also practiced ridging by removing the two front discs from the standard plow. These activities were almost all undertaken by contractors at a rate of 200-250 Thai baht (THB) per rai $(\$ 35-\$ 44 / \mathrm{ha})$. However, planting was done manually in all regions. About half the surveyed farmers planted directly into the plowed soil and half planted into preformed ridges (thought to prevent waterlogging and make harvesting easier). There was a widespread demand for a cassava planter, but current prototypes did not meet farmers' preference for vertical planting of cassava stakes. Pre-emergence herbicides were sprayed after planting to control weeds. Farmers used manual backpack sprayers, powered backpack sprayers, and high-pressure pumps to apply the herbicides; in the Northeast, 94 percent of farmers used a manual sprayer. Mechanical weeding was not observed.

Harvesting involved first manually cutting the cassava stems, which were collected for planting material, stacked for burning, or otherwise removed from the field. Most farmers then hired labor to lift the cassava roots using a locally developed harvesting tool that has spread to other Asian countries (Howeler and Aye 2014, 39). However, 37 percent of farmers in the Northern region, 27 percent in the Northeast region, and 24 percent in the Central region used a cassava digger attached to a 4WT (Chamsing 2013). Whether the roots were dug manually or with a tractor-drawn digger, the remaining tasks of collecting the lifted plants, cutting the roots from the stems, and loading the harvest into trucks were all done manually. There was interest from farmers in a prototype combined digger and hauler, but this needed further 
development. The cassava roots were loaded into small trucks, some owned by the farmer but most owned by collectors or contractors, for transportation to local factories. The roots were mechanically chopped and either sun-dried for production of chips or processed into starch.

\section{MAIZE}

In the 1950s, maize was planted on a small scale as a subsistence crop (for food and animal feed), mainly in the uplands and highlands of the Northern region. From 1961, maize was promoted as a commercial enterprise as part of the government's export-oriented diversification strategy (Ekasingh et al. 2004). It was increasingly planted as a rainfed crop on the undulating uplands, lower mountain slopes, foothills, and highlands of the Northern region (where its expansion was associated with extensive deforestation and soil erosion), as a rainfed crop on the upland plain of the Northeast region, and as a dry-season irrigated crop following wet-season rice on the lowland plain of the Central and lower Northern regions. The rainfed crop is almost entirely feed maize, whereas the irrigated crop includes sweet corn and baby corn. About half the maize area is in the Northern region and a quarter in each of the Central and Northeast regions. Almost 90 percent of maize is produced as a rainfed upland crop in the wet season (Ekasingh et al. 2004, 2007).

Maize production expanded rapidly in the 1970s and 1980s, almost entirely due to expansion in cultivated area. Most of this production was for export, which reached 4 million tons, valued at \$359 million, by 1986 . Beginning in the 1990s the area planted in maize declined as many upland farmers switched to other crops such as cassava and fruit trees, settling at about 1.1 million ha in the 2000s, but yields began to rise with increased use of improved varieties and fertilizers so that production has continued on an increasing trend. However, exports of maize plummeted from their peak in the late 1980s to be close to zero in the 1990s. The rapid growth of the domestic poultry and livestock sectors, which themselves have grown into export industries, increased the demand for feed within Thailand. Hence Thailand has been at times a net importer of maize, drawing on contract farming arrangements in neighboring countries.

Ekasingh and colleagues (2004) conducted a survey of maize producers in the main agroecological zones in 1999/2000. They found that all farmers used large 4WTs for land preparation, at least for the first pass, mostly on a contract basis. A majority of the surveyed areas were using various types of mechanical seeder, especially on large farms in flatter areas. However, on smaller farms on sloping land, the seed was planted manually. Farmers in the 
Central region planting maize in the dry season necessarily irrigated using the axial flow pumps that had become pervasive. Farmers sprayed pre-emergence herbicides after planting using manual or powered backpack sprayers, and followed up with mechanical weeding. In all the surveyed villages, harvesting was done manually, which was regarded by farmers as a significant cost. Often harvesting teams were contracted from other provinces or regions, particularly from the Northeast region. The harvested cobs were shelled mechanically by mobile machines provided on contract by the traders who purchased the grain. Ekasingh and others observed that "across Thailand, mechanization of farm operations is becoming a necessity for maize farmers, especially for land preparation, sowing, fertilizer application, and weeding. Small trucks are also used for transporting farm inputs and outputs" $(2004,19)$. Subsequently, Thai-made combine harvesters have been developed for maize, in response to demand from farmers to overcome the last remaining labor bottleneck. In the last decade these have been commercially produced and are increasingly used in flatter areas on a contract basis (Chiaranaikul n.d.).

\section{Factors Affecting the Supply of Mechanization}

As described above, the demand for agricultural mechanization came from millions of smallholder farmers engaged in production of rice and field crops for expanding global markets. These farmers were faced with increasing labor costs due to increased requirements for labor (arising from intensification of rice production and expansion of field crop production) and a declining agricultural labor force (due to slowing of population growth and rapid rural-to-urban migration resulting from industrialization). That the supply of mechanization was able to meet this demand, particularly in rice production, was due to the emergence and growth of local manufacturing capacity characterized by large numbers of small- to medium-scale enterprises and a few large firms in close communication with farmers and public-sector researchers. Small machinery firms typically employed 4 or 5 workers occupying a workshop of 50 square meters. They were located in close proximity to rice farms in the central plain. Large firms with 100 or more workers, occupying 3,000 square meters, also sprang up in the industrializing provinces to the north of Bangkok. The remarkable development of this agricultural machinery industry in Thailand has been outlined by Anchan (1983), Chancellor (1983), Rijk (1986, 1989), Thepent and Chamsing (2009), Thepent (2015), and Soni (2016). 
Imports of small-scale machinery from East Asia were also an important part of the mechanization story-as a direct source of supply, as models for local adaptation, and (crucially) providing components for incorporation in locally made machines. In particular, small, single-cylinder engines (of less than $16 \mathrm{hp}$ ) imported from Japan played a critical role in the early stages of the industry from the 1950 s to the 1970 s. These engines could be flexibly incorporated in locally designed pumps and tractors and thus used to power irrigation, cultivation, threshing, and transportation. By the early 1980s, about 80 percent of the single-cylinder diesel engines sold in the country were supplied by two local manufacturers under license from Japanese parent companies. ${ }^{4}$ These engines were more expensive but also more durable; they could be used for tractors, water pumping, boat propulsion, and powering a locally made transport vehicle (Chancellor 1983). The preference for diesel over gasoline engines reflected the lower price for diesel fuel (Biggs and Justice 2015).

\section{Policy Context}

Throughout Thailand's successive National Economic and Social Development Plans, beginning with the First Plan (1962-1966), there was no explicit policy regarding agricultural mechanization. Indeed, mechanization was not mentioned until the Sixth Plan (1987-1991). However, in 1979, the National Committee for Agricultural Mechanization was established to formulate a policy and strategy, which was approved by the cabinet in 1985 . This essentially affirmed the process that was already well underway, encouraging mechanization that increased productivity, with affordable machines of good quality that were suitable to the conditions of Thai farmers. This was despite concerns in some quarters about the capacity of mechanization to displace agricultural labor and cause excessive rural-to-urban migration (Anchan 1983), as well as to reduce agriculture's capacity to reabsorb labor during economic downturns (Coxhead and Plangpraphan 1998). The strategies involved collaboration between public and private sectors in research and development, standardization of machinery to enable certification, training of farmers and manufacturing workers, and facilitation of long-term credit for farmers and machinery businesses.

4 Siam Kubota Diesel Co. Ltd. and Yanmar Thailand Co. Ltd., both established in 1978 in Pathum Thani province, just north of Bangkok.

5 Standardization and certification have had limited impact. Testing is not feasible for smalland medium-scale manufacturers without assembly lines and, in any case, the local market disciplines these manufacturers without the need for formal certification. Testing is, however, enforced for the small one-cylinder engines that form an essential component of other 
The Seventh Plan (1992-1996) reiterated this general support for mechanization and promotion of local manufacturing and extension to farmers, but there was no explicit policy in this or subsequent plans. The Tenth and Eleventh Plans (spanning 2007 to 2016) made a significant shift to the notion of a "sufficiency economy," emphasizing sustainable agriculture, food security, bioenergy production, energy efficiency, and environmentally appropriate technologies, but none of these emphases has been interpreted or applied in a way to affect ongoing developments in mechanization.

Nevertheless, government institutions have played an important role in the development of the agricultural machinery industry since the 1950s, particularly in research and development. The Agricultural Engineering Division (AED), now the Agricultural Engineering Research Institute (AERI), under the Ministry of Agriculture and Cooperatives, developed blueprints and prototypes, linked with international research programs (for example, through a joint farm machinery development project with the International Rice Research Institute, or IRRI, from 1975 to 1985), and interacted closely with innovative private-sector manufacturers. ${ }^{6}$ The Small Industry Finance Corporation was established in 1964 and was a potential source of support to the emerging farm machinery industry, though it was "hampered by limited funds, which were dependent on state budget allocations, and cumbersome and inflexible government procedures and regulations" (SME Development Bank 2017). Its successor since 2002, the Small and Medium Enterprise Development Bank of Thailand (SME Development Bank), is much better resourced. The Thailand Board of Investment (BOI) also plays a role by offering tax breaks and other incentives to attract new projects from domestic and foreign manufacturers (Thepent 2015).

Though government institutions have been broadly supportive of mechanization, policy settings were not always favorable to the local industry. Reflecting on the first two decades of mechanization, Sukharomana remarked:

The farm power strategy of Thailand is remarkable in the sense that it has worked despite formidable handicaps... The government's most important contribution to the development of [the] farm machinery industry appears to be the initial importation of small tractors

machines, whether locally manufactured or imported. Certification for other machinery imports and exports is voluntary.

6 Professional and industry organizations have provided important links between the private sector, researchers, and government, including the Thai Society of Agricultural Engineers, established in 1976; the Agricultural Machinery Manufactures Industry Club, established in 1980; and the Thai Machinery Association, established in 2001 (Thepent 2015). 
from which local manufacturers borrowed [their] present technology. Having successfully borrowed, their industry has flourished with little government support-despite prevailing hostile fiscal policies and the government's indifference to industry needs. $(1983,31)$

According to Sukharomana, cheap credit through the Small Industry Finance Corporation had been "made available in a trickle" $(1983,6)$, with only three agricultural machinery firms acquiring loans. Sukharomana (1983) was particularly critical of the impacts of trade policy on local manufacturing, with low tariffs on imported machinery (including secondhand tractors) and excessive duties on components, particularly the imported diesel engines that were essential to the local industry. Donovan, Binswanger, and Pingali (1986) also pointed out that in the 1970s, local tractor production increased at 14 percent while the import share dropped below 7 percent- "despite negative protection." However, in 1981 imports of secondhand 2WTs from Japan surged, seriously undermining the domestic industry. ${ }^{7}$ In response to pressure from local manufacturers, in 1982 the government increased tariffs on imported machines and engines (from 5 to 35 percent) and established restrictive import quotas. In Anchan's words at the time, "clearly, the local manufacturing firms are now well protected" $(1983,12)$. This was consistent with policy toward the automotive industry (and industrial policy in general), which was protectionist from the 1960s to the 1980s, before the general liberalization of trade beginning in 1991 (Natsuda and Thoburn 2011), by which time the agricultural machinery industry was well established and starting to export locally made $2 \mathrm{WT}$ s and equipment to neighboring countries.

A broader aspect of the policy context relates to energy costs. As in many Asian countries, Thailand has long subsidized energy consumption via a complex set of measures (ADB 2015). Retail prices for diesel, liquefied petroleum gas (LPG), and natural gas for vehicles (NGV) are capped-in the case of automotive diesel at THB 30 (\$0.85) per liter, which is of considerable advantage to farmers using diesel pumps, tractors, and pick-ups. Price subsidies for diesel and NGV apply to all consumers, whereas LPG prices vary with the consuming sector. Electricity prices are subsidized for low-consuming households, as is the cost of providing electricity to rural and remote areas (where coverage is now close to 100 percent). Modeling suggests that removal of these subsidies without compensation or increased government spending on services

7 These $18 \mathrm{hp} 2 \mathrm{WTs}$ were recycled after perhaps only 2,000 hours of use, enabling importers to undercut the local product. 
would reduce the consumption levels of agricultural households and increase rural poverty, particularly in the Northern and Northeast regions, but only marginally, indicating that farmers are benefiting somewhat from the current regime (ADB 2015, 14-16). However, subsidy removal would benefit the agricultural machinery sector most, but harm the motor vehicle and vehicle repair sectors (ADB 2015, 17). This implies that the current regime has been, on balance, unfavorable to the agricultural machinery industry, though not greatly.

\section{Industry Size and Structure}

The agricultural machinery industry has been part of the growth and diversification of the manufacturing sector in Thailand. The Department of Industrial Works reported 2,809 businesses producing and repairing agricultural machinery in 2009 (Table 5.3). A survey in 2001 by the AERI found that 46 percent of agricultural machinery firms were small (with fewer than 10 employees), 34 percent were medium (10-30 employees), and 20 percent were large (more than 30 employees). Small firms typically have minimal equipment such as a simple lathe, follow flexible designs such that their products cannot be checked against a template, and employ workers on a daily wage without any fixed job descriptions or assignments. Medium firms have jigs and fixtures in addition to a simple lathe but still follow flexible designs and employ daily-paid labor. Large firms use computer numerical control (CNC) machining and possibly an automated machining center, follow a systematic manufacturing process that can be checked, and employ monthly-paid staff with specified job descriptions and assignments as well as daily-paid staff and contractors. ${ }^{8}$

The businesses enumerated in Table 5.3 produced mainly 2 WTs and tillage equipment, sprayers, and combine harvesters. More than 40 percent provided repairs and maintenance in small workshops scattered through the countryside. A survey of the top 70 agricultural machinery factories in Thailand in 2001 gave an indication of the production capacity, emphasizing the importance of $2 \mathrm{WTs}$, small tillage implements, sprayers, and pumps (Table 5.4). Two-wheel tractors and threshers last about 10 years, diesel engines about 7 years, and irrigation pumps and power sprayers about 6 years (Thepent 2000). Hence the output of 80,000 2WTs implies the capacity to maintain a stock of 800,000 on farms. This is just under half of the recorded

8 It is likely that the size distribution of machinery firms has shifted in the succeeding two decades, but no up-to-date study is available. 
TABLE 5.3 Number of agricultural machinery businesses, Thailand, 2009

\begin{tabular}{lc}
\hline Type of machinery & $\begin{array}{c}\text { No. of } \\
\text { businesses }\end{array}$ \\
\hline Two-wheel tractors & 275 \\
Tillage equipment & 329 \\
Planters & 16 \\
Sprayers & 447 \\
Harvesters & 386 \\
Other machinery & 164 \\
Repairs and maintenance & 1,192 \\
\hline
\end{tabular}

Source: Thepent (2014).

stock on rice farms in 2000, underlining the fact that imports of tractors and a range of other agricultural machinery remained important (Table 5.4).

Indeed, the Thai agricultural machinery industry has become increasingly integrated into the regional economy, with both imports and exports rising rapidly (Figure 5.4). According to Thailand BOI (2016), the value of agricultural machinery imports tripled between 2009 and 2014, to a total value of $\$ 1.11$ billion. The main sources of imports were Japan, China, and Malaysia. The largest imports by value were water pumps, tractor vehicles and parts, and mechanical sprayers. ${ }^{9}$ In the same period the value of agricultural machinery exports increased more than five times, to $\$ 0.79$ billion, led by $2 \mathrm{WTs}$ and equipment for cleaning, sorting, and grading seeds and grains (Thepent 2015; Thailand BOI 2016). The major export destinations were Cambodia, Myanmar, and Indonesia. Agricultural machinery and parts accounted for 7 percent of imports and 10 percent of exports of all machinery and parts in 2014 (Thailand BOI 2016).

\section{Development and Supply of Machinery}

\section{IRRIGATION PUMPS}

After the establishment of the Rice Department in 1953, the AED began work on improving imported machines and inventing machines suited to local conditions (Jongsuwat 1980). In the mid-1950s the AED developed a submersible low-lift axial flow pump (tho phayanak) powered by a small diesel

9 Electric-powered pump sets produced in southern China (Qiuqiong, Rozelle, and Hu 2007) have gradually replaced locally produced diesel-powered axial flow pumps as rural electrification has progressed. 
TABLE 5.4 Production of agricultural machinery in Thailand, 2001 and 2012

\begin{tabular}{lcc}
\hline & \multicolumn{2}{c}{ Production (units/year) } \\
\cline { 2 - 3 } Type of machinery & 2001 & 2012 \\
\hline Four-wheel tractors & - & 40,000 \\
Two-wheel tractors & 80,000 & - \\
Large tillage implements & 3,000 & - \\
Small tillage implements & 90,000 & - \\
Threshing machines & 2,000 & - \\
Combine harvesters & 600 & 3,000 \\
Hand-operated sprayers & 60,000 & - \\
Irrigation pumps & 55,000 & - \\
\hline
\end{tabular}

Source: BAC (2011) for 2001; Thepent (2014) for 2012.

Note: $-=$ data not available.

FIGURE 5.4 Imports and exports of agricultural machinery and parts, Thailand, 2009-2014

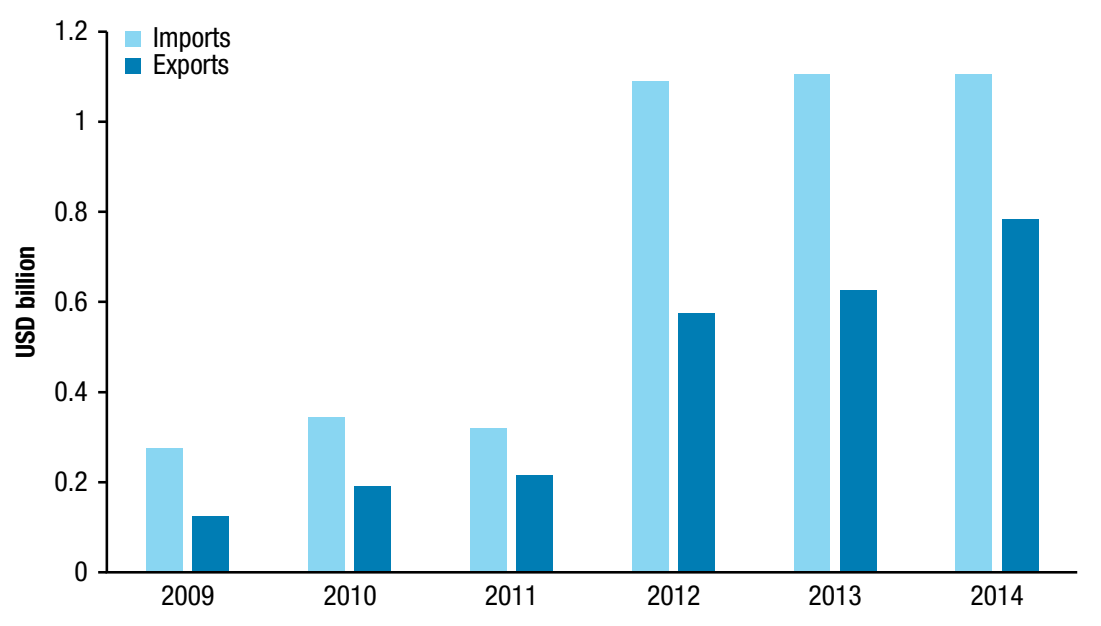

Source: Thailand BOI (2016).

Note: USD = US dollars.

engine of $4.5 \mathrm{hp}$, and in 1957 the design was released for local manufacture (Jongsuwat 1980). This "Debaridhi pump" (named after its inventor, M. R. Debaridhi Thevakul) was commercially produced and widely purchased or hired by farmers to lift water from rivers, canals, and ponds, and to drain rice fields. It very quickly replaced the traditional water wheels and scoops, and complemented (or compensated for) the large government-operated pumps in 
irrigation projects in the Chao Phraya delta (Molle, Shah, and Barker 2003). It was more efficient and cheaper to run than centrifugal pumps and could be easily transported. By enhancing their ability to irrigate, the pump helped to make dry-season cropping of rice and field crops economically attractive to lowland farmers. ${ }^{10}$

Versions of the Debaridhi pump are still widely used, often powered by 2WT engines (Figure 5.5). In 2001, 80 percent of irrigation pumps were in the Chao Phraya basin ( 55 percent in the Central region and 25 percent in the Northern), 15 percent in the Northeast, and 5 percent in the Southern region. By 2008 there were reported to be 1.43 million irrigation pumps in use, averaging THB 4,500 (\$126) per unit, for a total value of THB 6,439 million (\$180 million) (Thepent 2015). The 2013 agricultural census (Thailand, NSO 2013) found that 1.7 million holdings (29 percent) used an irrigation pump, 81 percent powered by a diesel engine and 19 percent by an electric motor (Table 5.1). Of these holdings, 78 percent of farmers owned a pump and 21 percent accessed a pump through a "service provider," often a neighboring farmer (Table 5.1).

\section{TRACTORS}

As in many countries even today (Pingali 2007; Animaw et al. 2016), there was initially a bias in official circles in favor of large tractors as the symbol of modernized agriculture (Chakkaphak and Cochran 1986). In 1891 the government imported some steam-powered tractors and rotary hoes, but these were expensive and unsuitable for use in paddy fields. In the early 1920s, further agricultural machines were imported for research and development, but there was little progress before the onset of World War II. In the early 1950s $4 \mathrm{WTs}$ were imported for use on the Rice Research Station and promoted through contract services to nearby farmers, but the project was unsuccessful. In 1958 the AED released the design of a small $25 \mathrm{hp} \mathrm{4WT} \mathrm{(the} \mathrm{"Iron}$ Buffalo") to two firms for commercial production, but the machine could not compete with imported tractors. In 1960 Ford established an assembly line for 4WTs, followed in 1964 by Massey Ferguson, but these were for use in dryland farming, not in rice production.

Two-wheel tractors were also imported in the decade after the war. In 1947, a single-axle tractor with rotary hoes powered by a $5.9 \mathrm{hp}$ gasoline engine was imported from Japan, but its low chassis made it unsuitable for

10 A similar development occurred in the Mekong delta in the 1960s, apparently independently of the Thai innovation (Biggs 2012). 
FIGURE 5.5 Use of two-wheel tractor to power an axial flow pump to irrigate a rice field in Central region, Thailand

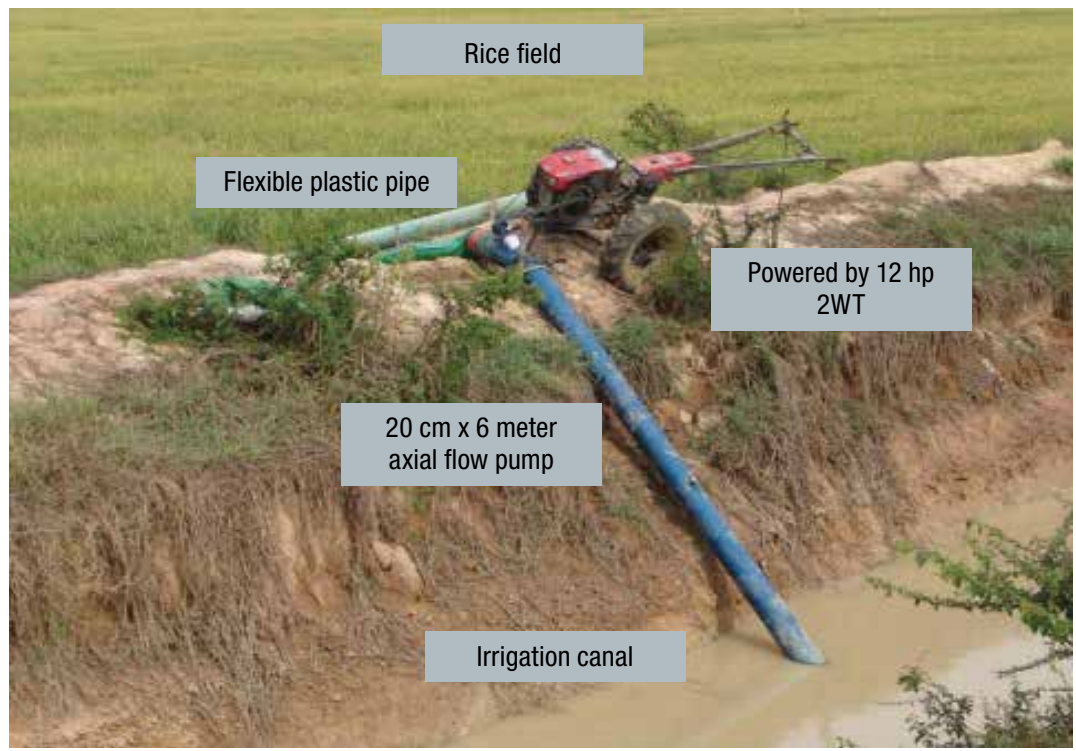

Photo: Scott Justice

Source: Scott Justice

paddy fields. Later, in the 1950s, a Japanese 2WT was imported and appeared more suitable. However, the major surge in the supply of tractors for rice farming began in the mid-1960s, when workshops around Bangkok began to modify the design of the imported 2WTs to meet farmers' demands for a cheaper and better-adapted version. One workshop succeeded in simplifying the gearbox and adapting other parts of the tractor, notably by lengthening the handles to enable easier turning in the muddy paddy fields. ${ }^{11}$ In 1966 several firms began producing these modified 2WTs, using imported air-cooled, singlecylinder gasoline engines. Their lower price relative to the imported tractors and their suitability to local conditions (for example, their greater maneuverability) made them popular with farmers, and they soon spread to all parts of the central plain. In a 1981/1982 survey of 222 farmers in an irrigated area of Suphanburi province, reasons given for using the 2WT were "save time

11 The producer of this first successful model was a village chief, Kamnan Prung Farkaew of the Singkru Dsahagrum factory in Phra Pradaeng, now part of Greater Bangkok (Jongsuwat 1980). 
in farm work" (22.8 percent), "can plant on time" (20.3 percent), "easy and reduces drudgery" (18.6 percent), "better plowing” (12.3 percent), "increases output" (5.6 percent), "no animal and human labor available" ( 4.2 percent), and "reduces weeding" (3.7 percent) (Sukharomana 1983).

The high demand led to the establishment of many farm machinery firms in this region. By the mid-1970s there were about 90,000 2WTs in use in Thailand, mostly (76 percent) in the Central region, and by 1981 there were more than 284,000 (Chancellor 1983; Sukharomana 1983). Almost all (95 percent) were locally manufactured by small firms, of which there were about 100 in 1979 (Sukharomana 1983). Small engineering workshops located in rural areas needed only a basic tool kit of an oxyacetylene torch for cutting and welding and an angle grinder to smooth cuts and joins. Mechanics learned their trade on the job and often subsequently set up their own small businesses. As the workshops were nearby the paddy fields, there was close interaction between farmers and mechanics in developing the tractors. Workshops would freely copy and adapt designs from existing machines and combine parts from different sources, and farmers would compare the performance of the machines and seek out better models. The tractors of the 1960s and 1970s incorporated the imported single-cylinder engines referred to above. By the 1980 s, they were mostly equipped with locally manufactured, liquid-cooled 8 hp diesel engines. These engines were more expensive but also more durable; they could be used also for water pumping, boat propulsion, and powering a locally made transport vehicle when not being used on the tractor (Chancellor 1983).

The 2WT was "so common and so simple in construction that any wellequipped workshop could effect repairs" (Chancellor 1983, 6). During the peak seasons, mechanical workshops worked long hours to repair farmers' machines. Mechanics' services were charged at THB $12.5(\$ 0.36)$ per hour in 1980/1981 (about twice the minimum wage for nonmetropolitan areas at that time). An excellent road network allowed rapid distribution of spare parts. Owners of the small, locally made tractors did about 30 percent of their own repairs and called on workshops for 60 percent (Chancellor 1983). Chancellor concluded that agricultural machinery systems in Thailand were marked by "an extensive general knowledge of machine repair techniques, a wide availability of low-cost machine repair services and a well-developed network of spare-parts supplies from import and domestic sources, so that repairs could be quickly effected" $(1983,6)$.

As reported in Table 5.1, by the 2013 agricultural census (Thailand, NSO 2013), 2.4 million holdings (41 percent) used 2 WTs, and in 75 percent 
of these holdings the tractor was owned by the landholder. Most of these holdings were rice farms. By this time a similar number of holdings used 4WTs, also mainly now manufactured or assembled in Thailand. These holdings were typically dryland farms growing field crops such as sugarcane, cassava, or maize. However, in the case of the larger tractors, 85 percent of holdings relied on service providers, typically larger landholders in the same district who gained extra income by renting out their tractors for land preparation. Larger tractors were more effective in cultivating the harder dryland soils but too expensive for most smallholders to own. However, the distinct uses of $2 \mathrm{WTs}$ and $4 \mathrm{WT}$ are becoming blurred. Thepent reported that "there is a growing market for a four-wheel tractor of less than $40 \mathrm{hp}$ with rotary implements which will replace two-wheel tractors for rice cultivation in the central plain region and the lower part of the Northern region" $(2015,4)$.

\section{PLANTERS}

Transplanting rice was a major bottleneck. As discussed above, farmers' main response was to move to direct seeding by hand broadcasting, in both irrigated and rainfed areas, first in the central plain, then spreading to the Northeast (Konchan and Kono 1996). In 1978, a rice transplanter was imported from China by a local firm, which also began manufacturing it (Chamsing and Singh 2000,3). The transplanter was power operated and capable of handling 12 rows. However, it could not be sold in large numbers because farmers preferred the simpler and cheaper broadcasting method. In recent years there has been renewed interest in the use of transplanters in parts of the central plain due to problems with contamination of rice varieties and weed control under direct seeding. Rice transplanters of less than $10 \mathrm{hp}$ include 4-row and 6-row walking types, and those of more than $10 \mathrm{hp}$ include 6-row and 8-row ride-on types. Sales of these transplanters have been increasing since 2010, though they still account for a small proportion of planted area (Ken Research 2016). All transplanters are imported from the Republic of Korea, Japan, and China, and are accessed through service providers.

Planting of dryland crops was also a peak labor requirement. Larger sugarcane farmers in the Central region had begun to use imported planters to reduce labor costs, as had larger maize farmers on flatter land in the Northern and Northeast regions. Maize seeders could be attached to $2 \mathrm{WTs}$ or $4 \mathrm{WTs}$, and some combined seeding and fertilizer application. However, despite the demand from farmers, there has been no commercial production of a cassava planter. 


\section{HARVEST AND POSTHARVEST MACHINERY}

The harvesting of rice, including the operations of reaping and threshing, constituted a second period of peak labor demand, especially where double cropping was practiced, and hence there was strong farmer interest in mechanizing these tasks. In 1975, the AED constructed a prototype axial flow rice thresher using a blueprint from the IRRI (Mongkoltanatas 1986). It was released to selected firms in Chachoengsao province (east of Bangkok) for commercial production, and 10 units were immediately sold. However, the design proved unsuccessful. Later, in 1975, a new blueprint was released to three firms for commercial production, and this version was rapidly and widely taken up by farmers. In 1977 IRRI sent a blueprint for a portable rice thresher. It was produced by one firm but not widely used due to its low capacity. Subsequent experimentation came up with a Thai thresher that doubled the capacity (from 1 to 2 tons per hour) and was self-propelled so it could be driven to the site (Sukharomana 1983; Mongkoltanatas 1986). This made it ideal for service provision by contractors.

During 1981/1982 about 1,000 Chinese reapers were imported and sold for rice harvesting. However, the long-stemmed Thai rice varieties were not suitable for reaping and, in any case, farm workers had to collect and bind the harvested rice as for manual harvesting, requiring more labor. In addition, the weight of the machines made field operations difficult. Hence the reapers were finally abandoned.

In the period 1985 to 1987, however, local machinery firms near Bangkok began to fabricate small track-type rice combine harvesters that could go into muddy and even flooded fields (Chiaranaikul n.d.). By the early 1990s, these firms had successfully launched a range of these track-type combine harvesters that were acceptable to farmers. They had a capacity of 0.4 to 0.9 ha per hour, providing a substantial saving, and were quickly taken up in the central plain through service providers. In 1997, there were about 2,000 harvesters, mainly in the central plain. As more contractors entered the industry, hiring rates came down. A survey by AERI for 1999/2000 found that 57 percent of rice farmers harvested with sickles, 35 percent used a combine, and 8 percent used a reaper; most farmers (88 percent) used a power thresher (Thepent 2000). Combine harvesters have since spread to the major rice-growing area of the Northeast, at first through itinerant contractors from the Central region who trucked their combines to the region and used local brokers to line up groups of adjacent farmers, then through local contractors in the Northeast who were capable of directly negotiating with neighboring farmers (Poungchompu and 
Chantanop 2016). According to the 2013 agricultural census, 1.6 million holdings ( 28 percent) used a combine harvester, in 97 percent of cases accessed through a contractor (Thailand, NSO 2013). Thus the spread of combines, even without land consolidation, has been more rapid and extensive than many analysts predicted (for example, Pingali 2007).

As the use of combines has spread, the domestic demand for reapers and threshers has understandably diminished (Table 5.1), though threshers are still produced for export to neighboring countries, using the same parts as are incorporated in the combine. At the same time, the high moisture content of grain harvested by combines has stimulated the development of a range of mechanical driers. The higher moisture content was because farmers could not dictate the date of harvesting, having to fit in with the contractor's schedule, and because the grain was no longer dried in the field as it was when threshing was conducted separately. The AERI has made a significant contribution to the design of these driers. In the late 1990s the government subsidized the installation of small driers (30 tons per day) for farmer groups and large driers (60 to more than 100 tons per day) for cooperative millers. However, only 10 percent of the farmer-operated driers were used, and mechanical drying is now largely undertaken by the rice mills (Thepent and Chamsing 2009).

Sugarcane harvesters have begun to be imported but were used by only 82,000 holdings ( 1 percent) in 2013 , almost all ( 96 percent) operated by contractors. Harvesting of cassava is still done largely by hand, using locally developed digging tools. According to Thepent (2015), a maize combine harvester has been available since 1995. From 2005 to 2007 the AERI modified the locally produced rice combine harvester to be suitable for maize (Chiaranaikul n.d.). Two models were developed, one with minor modifications, capable of harvesting $0.3-0.6$ ha per hour and one, with a four-row cob-snapping unit and modified threshing system, capable of harvesting $0.8-1.0$ ha per hour. Both models are now in commercial production and are increasingly used by maize farmers on a contract basis.

\section{TRANSPORTATION}

Though part of a broader trend, the harnessing of mechanical power for transportation, coupled with public investment in roads and infrastructure, has also had a profound effect on agricultural development. As mentioned above, one of the attractions of 2WTs in the 1960s and 1970s was the capacity to hitch them to a cart to make a multipurpose transport vehicle. The so-called pedestrian tractor thus became a means to haul people and produce 
much more easily than with a buffalo- or ox-drawn cart. Imported 4WTs also became a means of transportation for those who could afford them.

Meanwhile, the highly successful Thai automotive industry, a key component of the growth of the manufacturing sector, focused on the production of commercial vehicles, particularly pick-up trucks, which were highly suitable for conditions in rural areas (Natsuda and Thoburn 2011). Business or excise taxes had been set at lower rates than on passenger vehicles since the 1960s, adding to their attraction. The industry produced more than a million commercial vehicles in 2010. Many of these have been purchased by better-off farmers and rural dwellers, who use them to transport inputs, machinery, and produce for themselves and as a hired service to other farmers.

\section{Conclusion}

Agricultural mechanization in Thailand has a long and multistranded history, illustrating the importance of context in assessing alternative models of agricultural development. The demand for mechanization came from millions of small-scale farming households seeking to employ new technologies to intensify and expand their production of rice and commercial field crops in response to domestic and global markets, while faced with a growing shortage and increasing cost of farm labor due to rapid economic and demographic change. The supply of suitable machinery and tools came initially from small-scale workshops that were responsive to farmers' needs and were willing and able to borrow ideas and experiment with piecing together available parts (especially single-cylinder engines) to make new and better-adapted machines.

The sequence of mechanization in Thailand conforms well to the generalizations advanced by Binswanger (1986) and Pingali (2007). The first wave of mechanization involved the use of small-scale, power-intensive multipurpose machines, notably low-lift axial flow pumps and 2WTs. This was particularly the case for rice cultivation, whereas opening up dryland for sugarcane, maize, and cassava made greater use of 4WT-drawn implements. Later waves of mechanization involved larger-scale, control-intensive, specific-purpose machines, notably threshers, combine harvesters, and most recently, rice transplanters. Although most farmers could afford to purchase the small-scale machines, the larger, more costly machines (including 4WTs) were made widely available by the emergence of contract services provided by a class of better-off entrepreneurial farm households. Early mechanization copied, adapted, and substituted for imported machinery. Subsequently, the 
agricultural machinery industry became integrated into the wider regional economy, with rapid growth in both imports and exports.

The experience in Thailand supports Binswanger's generalization that "the rate and pattern of mechanization are governed substantially by an economy's land and labor endowments, by the nonagricultural demand for labor, and by demand for agricultural products" (1986, 27; see also Pingali 2007). The path of mechanization in Thailand was clearly induced by the increasing scarcity and cost of labor relative to land, partly driven by rapid growth in nonagricultural demand for labor, in the context of elastic (export) demand for rice and the major field crops. However, in this case, there was very little influence of public-sector researchers, nor of organized farmer associations-both seen as essential elements in the induced innovation hypothesis as first formulated by Hayami and Ruttan (1971). Rather, direct and informal links between smallholders and small-scale local manufacturers (the private sector) provided the impetus for the adaptation and development of machinery that was initially "good enough" for local needs.

As for policy recommendations for African countries, Thai experiences suggest that the role of government has been important but secondary, and has been more effective in keeping the private informal sector active. The government played roles in research and sharing of designs with private manufacturers, at times providing incentives and trade protection for the emerging domestic industry. It had also focused on rural electrification; subsidizing energy costs, especially diesel fuel; and providing affordable and widely available farm credit. More generally, the government has adopted a light-handed approach, supporting agricultural mechanization as a positive contribution to rural development but allowing the private sector-manufacturers, dealers, contractors, and farmers-to innovate in response to changing technology and markets. Its experiences also show that tractors can be widely used not only for crops like rice and wheat, but also for crops like sugarcane and maize, as well as root crops like cassava, even though in Africa, where these crops are widely grown, applications of tractors have conventionally been thought difficult. The Thailand case thus shows that, despite widespread neglect of engineering technologies relative to biological technologies in international policy debates and research, mechanization can play a significant role in broad-based agricultural and rural development. In particular, mechanization is compatible with smallholder-led development, through both small-scale, multipurpose machines owned by farmers and large-scale, specialized machines made accessible through private contract services. It is also compatible with (indeed, partly induced by) intensification via the utilization of conventional Green 
Revolution (seed-fertilizer-irrigation) technologies, especially in rice-based farming systems.

\section{References}

ADB (Asian Development Bank). 2015. Fossil Fuel Subsidies in Thailand: Trends, Impacts, and Reforms. Manila.

Anchan, T. 1983. Farm Mechanization Policy in Thailand. Working Paper No. 104, Consequences of Small Farm Mechanization Project. Bangkok: Kasetsart University.

Animaw, A. T., J. A. M. Nkanya, J. M. Nyakiba, and T. H. Woldemariam. 2016. Agricultural Mechanization and South-South Knowledge Exchange: What Can Ethiopian and Kenyan Policymakers Learn from Bangladesh's Experience? Ethiopia Strategy Support Program Research Note 47. Washington, DC: International Food Policy Research Institute.

Australian National University. 2019. CartoGIS. Accessed 4 April. http://asiapacific.anu.edu.au/ cartogis/.

BAC (Business Analytic Center). 2011. Farm Machinery Market in Thailand: Business Report 2011. Bangkok.

Biggs, D. 2012. "Small Machines in the Garden: Everyday Technology and Revolution in the Mekong Delta." Modern Asian Studies 46: 47-70.

Biggs, S., and S. Justice. 2015. Rural and Agricultural Mechanization: A History of the Spread of Small Engines in Selected Asian Countries. IFPRI Discussion Paper 01443. Washington, DC: International Food Policy Research Institute.

Binswanger, H. 1986. “Agricultural Mechanization: A Comparative Historical Perspective.” World Bank Research Observer 1:27-56.

Chakkaphak, C., and B. Cochran. 1986. "Development of Four-Wheel Tractors and Implements in Thailand." In Proceedings of the International Conference on Small Farm Equipment for Developing Countries, 151-159. Los Baños, Philippines: International Rice Research Center.

Chamsing, A. 2013. Agricultural Mechanization Technologies for Production and Processing of Cassava in Thailand. Bangkok: Agricultural Engineering Research Institute, Ministry of Agriculture and Cooperatives, Thailand.

Chamsing, A., and G. Singh. 2000. "Rice Mechanization and Processing in Thailand." Agricultural Mechanization in Asia, Africa and Latin America 33: 21-30.

Chancellor, W. J. 1983. The Sustainability of Mechanization in Thailand. Working Paper No. 98, Consequences of Small Farm Mechanization Project. Bangkok: Asian Institute of Technology. 
Chapman, E. C. 1978. "Shifting Cultivation and Economic Development in the Lowlands of Northern Thailand." In Farmers in the Forest: Economic Development and Marginal Agriculture in Northern Thailand, edited by P. Kunstadter, E. C. Chapman, and S. Sabhasri, 222-235. Honolulu: East-West Center.

Chiaranaikul, K. n.d. “Thai Rice Combine Harvesting.” PowerPoint presentation, Agricultural Engineering Research Institute, Thailand Ministry of Agriculture and Cooperatives, Bangkok.

Chinsuwan, W., and B. J. Cochran. 1986. “The Axial Flow Low Lift Pump in Thailand.” In Proceedings of the International Conference on Small Farm Equipment for Developing Countries, 195-203. Los Baños, Philippines: International Rice Research Center.

Coxhead, I., and J. Plangpraphan. 1998. Thailand's Economic Boom and Agricultural Bust: Some Economic Questions and Policy Puzzles. Staff Paper Series No. 419. Madison: Department of Agricultural and Applied Economics, University of Wisconsin.

Cramb, R. A. 2015. "Introduction." In Trajectories of Rice-Based Farming Systems in Mainland Southeast Asia. ACIAR Monograph No. 177, edited by R. A. Cramb, 1-16. Canberra: Australian Center for International Agricultural Research.

Cramb, R. A., and J. C. Newby. 2015. "Trajectories of Rice-Farming Households in Mainland Southeast Asia." In Trajectories of Rice-Based Farming Systems in Mainland Southeast Asia. ACIAR Monograph No. 177, edited by R. A. Cramb, 35-72. Canberra: Australian Center for International Agricultural Research.

Curran, S. R., and A. M. Cooke. 2008. "Unexpected Outcomes of Thai Cassava Trade: A Case of Global Complexity and Local Unsustainability." Globalizations 5: 111-127.

De Koninck, R., and J. Rousseau. 2012. Gambling with the Land: The Contemporary Evolution of Southeast Asian Agriculture. Singapore: NUS Press.

Ding, Q. S., B. Tangwongkit, and R. Tangwongkit. 2004. "Manual Sugarcane Harvesting System vs. Mechanical Harvesting System in Thailand." Agricultural Mechanization in Asia, Africa and Latin America 35: 33-36.

Donovan, G., H. Binswanger, and P. Pingali. 1986. "Farm Mechanization Issues and Policies." In Proceedings of the International Conference on Small Farm Equipment for Developing Countries, 23-34. Los Baños, Philippines: International Rice Research Center.

Ekasingh, B., P. Gypmantasiri, K. Thong-ngam, and P. Grudloyma. 2004. Maize in Thailand: Production Systems, Constraints, and Research Priorities. Mexico City: International Maize and Wheat Improvement Center (CIMMYT).

Ekasingh, B., C. Sungkapitux, J. Kitchaicharoen, and P. Suebpongsang. 2007. Competitive Commercial Agriculture in the Northeast of Thailand. Department of Agricultural Economics and Multiple Cropping Center, Faculty of Agriculture, Chiang Mai University, Thailand. 
FAO (Food and Agricultural Organization of the United Nations). 2017. FAOSTAT database. Accessed 18 November. http://faostat.fao.org.

Fujimoto, A., K. Adulavidhaya, and T. Matsuda, eds. 1990. Thai Rice Farming in Transition. Tokyo: World Planning.

Grandstaff, T. B., S. Grandstaff, V. Limpinuntana, and N. Suphanchaimat. 2008. "Rainfed Revolution in Northeast Thailand." Southeast Asian Studies 46: 289-376.

Hayami, Y., and V. Ruttan. 1971. Agricultural Development: An International Perspective. Baltimore: Johns Hopkins University Press.

Howeler, R., and T. M. Aye. 2014. Sustainable Management of Cassava in Asia: From Research to Practice. Cali, Colombia: International Center for Tropical Agriculture.

Jongsuwat, N. 1980. Productivity Growth and Farm Machinery Adoption in Thai Agriculture. Master's thesis, Faculty of Economics, Thammasat University, Bangkok.

Ken Research. 2016. Thailand Agricultural Machinery Market Outlook to 2020. Haryana, India. Accessed January 25, 2017. www.kenresearch.com/agriculture-and-animal-care/agriculture -equipment/thailand-farm-equipment-implements-market/25252-104.html.

Klyuev, V. 2015. Structural Transformation: How Does Thailand Compare? IMF Working Paper 15/51. Washington, DC: International Monetary Fund.

Konchan, S., and Y. Kono. 1996. "Spread of Direct Seeded Lowland Rice in Northeast Thailand: Farmers' Adaptation to Economic Growth.” Southeast Asian Studies 33: 523-546.

Kupkanchanakul, T. 2000. "Bridging the Rice Yield Gap in Thailand.” In Bridging the Rice Yield Gap in the Asia-Pacific Region, edited by M. K. Papademetriou, F. J. Dent, and E. M. Herath, 146-156. Bangkok: Food and Agriculture Organization of the United Nations Regional Office for Asia and the Pacific.

Leturque, H., and S. Wiggins. 2011. Thailand's Progress in Agriculture: Transition and Sustained Productivity Growth. London: Overseas Development Institute.

Molle, F., T. Shah, and R. Barker. 2003. "The Groundswell of Pumps: Multilevel Impacts of a Silent Revolution." Paper prepared for International Commission on Irrigation and Drainage, Asia Meeting, Taiwan, November.

Mongkoltanatas, J. 1986. “Axial-Flow Paddy Threshers in Thailand.” In Proceedings of the International Conference on Small Farm Equipment for Developing Countries, 389-398. Los Baños, Philippines: International Rice Research Center.

Natsuda, K., and J. Thoburn. 2011. Industrial Policy and the Development of the Automotive Industry in Thailand. Ritsumeikan Center for Asia Pacific Studies Working Paper No. 11-5. Beppu, Oita, Japan: Ritsumeikan Asia Pacific University. 
Ouyyanont, P. 2016. Rural Thailand: Change and Continuity. Trends in Southeast Asia No. 8. Singapore: Institute for Southeast Asian Studies.

Pingali, P. 2007. "Agricultural Mechanization: Adoption Patterns and Economic Impact." In Handbook of Agricultural Economics. Vol. 3, edited by R. Evenson and P. Pingali , 2779-2805. Amsterdam: Elsevier.

Poapongsakorn, N. 2006. “The Decline and Recovery of Thai Agriculture." In Rapid Growth of Selected Asian Economies: Lessons and Implications for Agriculture and Food Security, Part 2. Bangkok: Regional Office for Asia and the Pacific, Food and Agriculture Organization of the United Nations.

Poungchompu, S., and S. Chantanop. 2016. "Economic Aspects of Rice Combine Harvesting Service for Farmers in Northeast Thailand." Asian Social Science 12: 210-211.

Qiuqiong, H., S. Rozelle, and D. Hu. 2007. "Pump-Set Clusters in China: Explaining the Organization of the Industry That Revolutionized Asian Agriculture." Asia-Pacific Development Journal 14 (2): 75-105.

Ramsay, A. 1985. "Population Pressure, Mechanization, and Landlessness in Central Thailand." Journal of Developing Areas 19: 351-368.

Rerkasem, B. 2015. “The Agroecosystem of Thai Rice: A Review." CMU Journal of Natural Science 14: $1-21$.

Rigg, J. 2012. Unplanned Development: Tracking Change in South-East Asia. London: Zed Books.

Rijk, A. G. 1986. "The Role of Farm Mechanization in Developing Countries: Experience in Asian Countries." In Proceedings of the International Conference on Small Farm Equipment for Developing Countries, 3-21. Los Baños, Philippines: International Rice Research Center.

— 1989. Agricultural Mechanization Policy and Strategy: The Case of Thailand. Tokyo: Asian Productivity Organization.

Singhapreecha, C. 2014. "Economy and Agriculture in Thailand." Agricultural Policy Platform, Food and Fertilizer Technology Center for the Asia Pacific Region. Accessed December 7, 2016. http://ap.fftc.agnet.org/ap_db.php?id=246.

SME Development Bank. 2017. “Small and Medium Enterprise Development Bank of Thailand.” Accessed January 27. www.smebank.co.th/en/about.php.

Soni, P. 2016. "Agricultural Mechanization in Thailand: Current Status and Future Outlook." Agricultural Mechanization in Asia, Africa and Latin America 47: 58-66.

Srijantr, T. 2003. "Agrarian Transformations in the Chao Phraya Delta: A Case Study in Tambon Thung Luk Nok." In Thailand's Rice Bowl: Perspectives on Agricultural and Social Change in the Chao Phraya Delta, edited by F. Molle and T. Srijantr, 125-150. Bangkok: White Lotus Press. 
Sukharomana, S. 1983. The Farm Power Strategy of Thailand. Working Paper No. 75,

Consequences of Small Farm Mechanization Project. Bangkok: Kasetsart University.

Thailand, BOI (Board of Investment). 2016. Thailand's Machinery Industry. Bangkok.

Thailand, NSO (National Statistical Office). 2013. 2013 Agricultural Census. Bangkok.

Thepent, V. 2000. Agricultural Machinery and Mechanization Situation in Thailand. Country

Report. Bangkok: Agricultural Engineering Research Institute, Thailand.

_ 2014. "Country Presentation Paper: Thailand." Presented at Regional Roundtable of

National Agricultural Machinery Associations in Asia and the Pacific, Wuhan, China,

October 28-30. http://un-csam.org/ppta/201410wuhan/9TH.pdf.

-2015. Agricultural Mechanization in Thailand. Centre for Sustainable Agricultural

Mechanization Policy Brief No. 6. Bangkok: UN Economic and Social Commission for Asia and the Pacific.

Thepent, V., and A. Chamsing. 2009. Agricultural Mechanization Development in Thailand.

Paper presented at fifth session of Technical Committee of Asian and Pacific Centre for Agricultural Engineering and Machinery, Los Baños, Philippines, October 14-16.

Tijaja, J. 2010. “The Impact of China’s Demand on Domestic Value Chains: Lessons from the Cassava Value Chains in Thailand." Paper presented at annual conference of the Chinese Economic Association (UK and Europe), Oxford, UK, July 12-13.

Tomich, T., P. Kilby, and B. F. Johnston. 1995. Transforming Agrarian Economies: Opportunities Seized, Opportunities Missed. Ithaca, NY: Cornell University Press.

USAID (US Agency for International Development). 2011. "Property Rights and Resource

Governance: Thailand-Country Profile." Accessed December 20, 2016. www.land-links .org/country-profile/1548/.

USDA (US Department of Agriculture). 2016. Thailand Biofuels Annual 2016. Global

Agricultural Information Network Report No. TH6075. Washington, DC: USDA Foreign Agricultural Service.

Vorasayan, J., and S. Pathumnakul. 2014. "Optimal Logistics System for Sugarcane Mechanical Harvesting in Thailand." Journal of Applied Science and Agriculture 9: 28-35.

Warr, P. 2007. “Long-Term Economic Performance in Thailand.” ASEAN Economic Bulletin 24: $138-163$.

- 2014. "Agricultural Liberalization, Poverty, and Inequality: Indonesia and Thailand." Journal of Asian Economics 35: 92-106.

Weerathaworn, P. 2015. “Sugar Industry in Thailand.” Presentation at Agri Benchmark Cash Crop Conference, Goiania, Brazil, July. 
World Bank. 2016. Thailand: Getting Back on Track, Reviving Growth and Securing Prosperity for All. Bangkok.

— 2017. World Bank Open Data database. Accessed March 28. https://data.worldbank.org /about/get-started.

Zhang, X., J. Yang, and T. Reardon. 2015. Mechanization Outsourcing Clusters and Division of Labor in Chinese Agriculture. IFPRI Discussion Paper 01415. Washington, DC: International Food Policy Research Institute. 
